\title{
II \\ In Defense of Pay-as-You-Go (Paygo) Financing of Social Security
}

\author{
by Robert L. Brown
}

\begin{abstract}
Today's proposals to create larger social security funds and then invest them in the private sector are intended to create more rapid economic growth, which would make it easier to pay social security benefits in the long run. These proposals are also aimed at enhancing intergenerational equity by making today's workers pay for a greater proportion of their future benefits.

The important public policy issues inherent in such proposals are numerous: questions of whether prefunded social security plans are demographically immune; whether prefunding social security can increase gross national savings and worker productivity; whether there are better ways to create a healthy economy; whether social security is best offered as a defined-benefit or a defined-contribution plan. This paper explores each of these important public policy issues in the context of the social security systems of Canada and the U.S.
\end{abstract}

\section{Introduction}

This paper discusses the issues surrounding the level of funding for the social security systems in Canada and the U.S., which is an important public policy agenda item at this time. The paper does not present a balanced discussion of the issues; rather, it presents a defense of payas-you-go (paygo) financing as the preferred method. Many authors are now speaking in favor of a more fully funded system (see, for example, Robson 1995, Slater
1995, World Bank 1994, and Kotlikoff et al. 1996), and they appear to have the ear of policymakers.

In short, my purpose is to pose important questions that need to be answered by policymakers before any move is made to larger prefunding of social security.

I think that actuaries, by their training, have a natural predisposal to favor prefunding. As stated by Miles Dawson (1917): "actuaries approach it as if it were settled in advance that there ought to be a reserve and after a good deal of study and investigation are not so certain they are right."

For the following discussion, the meanings of the words paygo and funded need to be carefully understood. Neither word is taken in its absolute meaning. For example, paygo funding is not to meant to imply no contingency fund at all. In fact, the paper assumes that any system that carries only a small contingency (no more than two years of benefit expenditures) is a paygo system. Similarly, funded does not mean absolutely fully funded; any scheme that creates investable funds measurably larger than a small contingency reserve is included in the category of "prefunded" schemes.

The Old Age and Survivors Insurance and Disability Insurance (OASDI) system today has a fund that is expected to grow for the next decade or so. However, that fund is not expected to exceed two years' worth of benefit expenditures (or if so, only slightly). Thus, this paper categorizes the OASDI system as paygo. Similarly, the Canada/Quebec Pension Plan (C/QPP), today, carries a side fund of about two years' worth of benefits; thus, this paper refers to the C/QPP as paygo today. However, recent government amendments to the 
plan would raise the contribution rate by $73 \%$ over the next six years and create a fund worth five years of benefit expenditures. Thus, the amended C/QPP is not referred to as paygo.

One important aside is the stability of contributions, an issue often raised as a public policy goal of any financing scheme for social security (certainly it was a prime motivating factor for recent amendments to the $\mathrm{C} / \mathrm{QPP}$ ). As discussed in the next section, the contribution rates for a fully funded scheme are a function of the real rates of return earned by the funds. Thus, a truly fully funded scheme does not create stable contribution rates. Rates rise and fall inversely to real interest rates. However, contribution rates fluctuate more than interest rates because each year's contribution must cover both the value of the benefits earned for the year and the actuarial experienced gain or loss on the benefits for all past years.

A pure paygo system has contribution rates that rise and fall with the ratio of retirees to workers and the rate of increase of national incomes. Thus, a pure paygo system also cannot have stable contribution rates. Both systems require immediate attention if any variable evolves other than the modeled expectations. However, either a paygo system with a small contingency fund or a partially funded system that can use its reserves to soften the immediate need for contribution rate changes can result in achieving level and stable contribution rates for long periods.

\section{Why the Interest in Prefunding Social Security?}

Many industrialized nations are currently considering some form of prefunding of their social security systems; this is certainly true in Canada and the U.S. Proposals that have been put forth to change social security range from relatively small (for example, how a small proportion of surplus assets are invested) to very dramatic (for example, the total replacement of the present social security system with individual savings accounts, such as in Chile).

The supporters of these various proposals claim that today's younger workers and tomorrow's working generation will be better off with a changed social security system. But after a half century of relative stability in the philosophical underpinnings of social security, why the apparent sudden interest in change?

One of the driving forces for reform is the impending dramatic shift in the demographics underlying social security. These forces have been widely analyzed and are well understood. First, life expectancy has improved substantially and is continuing to improve. Statistics for Canada and the U.S. are given in Tables 1 and 2.

More important, however, are the impending demographic dependency shifts as we anticipate the movement of the baby boom out of the labor force and its replacement by the baby-bust cohort. This fast-approaching force is seen clearly in Figures 1 (Canada) and 2 (the U.S.).

\section{TABLE 1}

LIFE EXPECTANCY IN CANADA

\begin{tabular}{cccccc}
\hline & \multicolumn{2}{c}{ At Birth } & & \multicolumn{2}{c}{ At Age 65 } \\
\cline { 2 - 3 } \cline { 5 - 6 } Year & Male & Female & & Male & Female \\
\hline 1921 & 58.8 & 60.6 & & 13.0 & 13.6 \\
1961 & 68.4 & 74.2 & & 13.5 & 16.1 \\
1991 & 74.6 & 80.9 & & 15.7 & 19.9 \\
\hline
\end{tabular}

Source: Statistics Canada.

TABLE 2

LIFE EXPECTANCY IN THE U.S.

\begin{tabular}{cccccc}
\hline & \multicolumn{2}{c}{ At Birth } & & \multicolumn{2}{c}{ At Age 65 } \\
\cline { 2 - 3 } \cline { 5 - 6 } Year & Male & Female & & Male & Female \\
\hline 1920 & 55.6 & 57.6 & & 12.2 & 12.7 \\
1960 & 66.8 & 73.2 & & 12.9 & 15.8 \\
1990 & 71.8 & 78.8 & & 15.1 & 19.0 \\
\hline
\end{tabular}

Source: U.S. Life Tables.

\section{Figure 1 \\ Live Births in Canada 1920-1995}

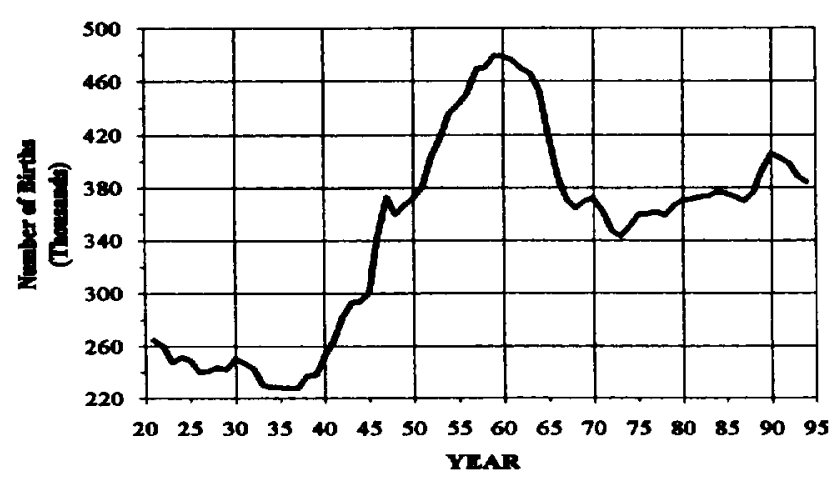

From R.L. Brown. Introduction to the Mathematics of Demography. 3rd ed Winsted, Conn.: Actex Publications, 1997. Copyright $(1997$. Reprinted with permission. 


\section{Figure 2 \\ LIVE BIRTHS IN THE U.S. 1920-1995}

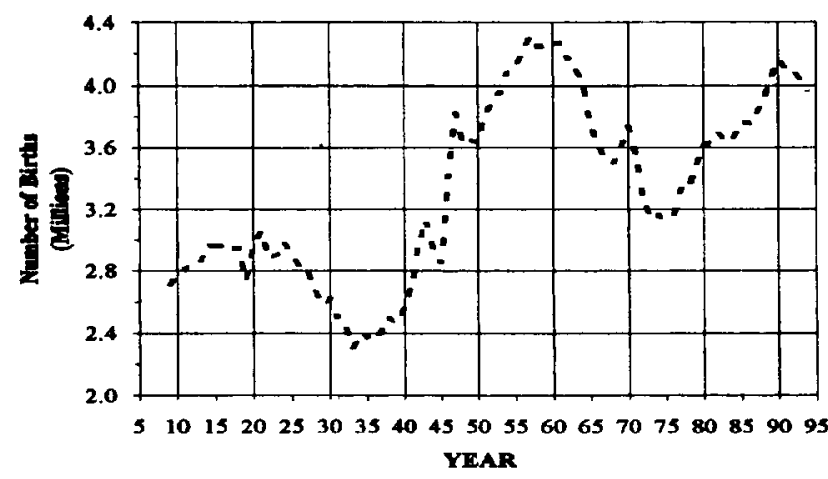

From R.L. Brown. Introduction to the Mathematics of Demography. 3rd ed. Winsted, Conn.: Actex Publications, 1997. Copyright (C 1997. Reprinted with permission.

We have already experienced the economic impact of the baby boom in its youth and in its entry into the labor force. When baby boomers bought homes, house prices and mortgage rates rose measurably. When they entered the workforce, youth unemployment rates skyrocketed. Their entry into the labor force has also been blamed for dampening rates of productivity improvement as business chose to buy cheap labor instead of more expensive capital.

Those who favor prefunding of social security to some extent argue that the resultant large asset pools can be invested to aid in overcoming the impact of these demographic shifts on paygo contribution rates. Through enhanced economic growth, it is said, faster wealth creation makes larger wealth transfers possible. For example, assume that the cost of retirement income security and health care for the aged today costs $12.5 \%$ of all wages from all workers. That means that a worker who is paid for a 40-hour week has to work five hours to fund the benefits for the dependent elderly. Assume that over the next 35 years the ratio of elderly to workers doubles. With no change in worker productivity, each worker would have to contribute $25 \%$ of wages, or work ten hours, to take care of the benefits for the dependent elderly. However, if every worker were to become twice as productive (which would require only $2 \%$ improvement per annum for those 35 years), then each worker would produce enough goods and services to meet the needs of the dependent elderly in the same five hours it takes today.
In terms of the direct funding of social security in Canada and the U.S., the ability of enhanced worker productivity to solve the financing problems as projected is more limited. In both Canada and the U.S., the accrual of benefits is linked to a wage base that is indexed to national wages. Thus, any productivity improvements that are reflected in national wages prior to retirement immediately create larger social security benefits at retirement. After retirement, again in both Canada and the U.S., benefits are indexed to cost of living as measured by the consumer price index (CPI). Thus, it is only after retirement that increased worker productivity creates a discount rate in terms of the cost of social security. To achieve the full cost benefit of gains in productivity, price-indexed pre-retirement formulas would be necessary. For a full discussion of this matter, see Moorhead and Trowbridge (1977).

If prefunding social security results in faster wealth creation, then why wasn't social security established on a fully funded basis from the beginning? (For a more complete discussion of the history of this debate within OASDI, see Derthick 1979, Chapters 10-11.)

If social security is financed on a (paygo) basis, then the implicit "rate of return" of such a financing arrangement is the rate of increase of employment earnings (subject to social security contributions); see, for example, Treuil (1981). This, in turn, is normally highly correlated to the total of the growth rate of the labor force (including part-time work) and the perworker rate of productivity increase.

A fully funded social security scheme has an actuarial discount rate equivalent to the real rate of interest (real rates because social security benefits are indexed to inflation).

According to the Canadian Institute of Actuaries (1996, p. 3), in the 1960s demographic and economic variables, if assumed long term into the future (after a ten-year transition from existing values), favored paygo financing on the basis of cost. In particular, in the 1960s in Canada (when the C/QPP was introduced on a quasi-paygo basis), reasonable actuarial assumptions would have been as follows:

$$
\begin{array}{ll}
\text { Senior dependency ratio } & 0.33 \\
\text { Annual increase in real wages } & 2.0 \% \\
\text { Real rates of return } & 2.0 \%
\end{array}
$$

These underlying assumptions would have led to the following projected costs for Canadian social security as a percentage of payroll for paygo versus fully funded arrangements. 


$\frac{\text { Funding Arrangement }}{\text { Paygo (mature plan) }} \frac{\begin{array}{c}\text { Projected Cost as } \\ \text { Percentage of Payroll }\end{array}}{\text { Fully funded }} \frac{11.0 \%}{16.5 \%}$

But times have changed. The future is not what it used to be. Today's long-term assumptions (again after a ten-year transition from existing values) in Canada would be closer to the following (CIA 1996):

$\begin{array}{ll}\text { Senior dependency ratio } & 0.40 \\ \text { Annual increase in real wages } & 1.0 \% \\ \text { Real rates of return } & 4.0 \%\end{array}$

These factors lead to the following projected costs:

$\begin{array}{ll}\text { Funding Arrangement } & \begin{array}{c}\text { Projected Cost as } \\ \text { Percentage of Payroll }\end{array} \\ \text { Paygo (mature plan) } & 14.5 \% \\ \text { Fully funded } & 7.2 \%\end{array}$

While factors in the U.S. would not favor prefunding to the same extent, because real interest rates are lower and annual wage increases higher than in Canada, the forces now favor fuller funding in the U.S. as well.

This explains the pressure to consider a shift to greater funding of social security. Just as paygo financing makes sense for cost containment when real interest rates are lower than the growth rate of real wages (as in the 1950s and 1960s), so too a conversion to more funding seems to make sense when real interest rates are higher than real wage growth prospects (as in the 1990s).

But is a prefunded scheme more secure? Can productivity rates be increased by prefunding social security? Are prefunded plans demographically immune? How long will factors favoring prefunding last? Would switching back and forth between financing arrangements be accepted as good public policy? These are the questions that should be posed by public policymakers before any switch in funding methods is adopted. The rest of the paper explores many of these issues.

\section{Is a Funded Pension Demographically Immune?}

One problem with any discussion around the optimal financing arrangement for social security is confusion between what is true on a microeconomic basis and what is true on a macroeconomic basis.
This is sometimes referred to as the "Fallacy of Composition," whereby it is assumed that what is true for an individual will necessarily be true in aggregate (see Barr 1993 and Krugman 1996). For example, if I stand at a concert, I can see better, but if everyone stands, then no one has an improved view. Clearly, for an individual to save for retirement, consumption must be foregone during one's working lifetime, with money set aside in savings. These funds are then used to buy goods and services post-retirement. Thus, it would seem logical for a nation to provide for its citizens' post-retirement needs by designing a prefunded social security scheme that accumulates large account balances that can be used to fund post-retirement consumption.

Francisco Bayo (1988, p. 178), deputy chief actuary of OASDI, says this turns out not to be true:

For Social Security, you cannot accumulate assets; that is, claims from somebody else's production. If we have a large amount of money in the Social Security tnust funds, we have a claim on ourselves, which does not have much meaning. The truth is, whatever is going to be consumed - be it a product that you can get a physical hold of, or services that are very difficult to holdthose products cannot be stockpiled. They have to be provided at the time of consumption. No matter what kind of financing we are going to have in our Social Security program, you will find that the benefits that will be obtained by the beneficiary in the year 2050 will have to be produced by the workers in the year 2050 , or just a few years earlier.

Nicholas Barr (1993, p. 220) says it even more strongly:

The widely held (but false) view that funded schemes are inherently "safer" than PAYGO is an example of the fallacy of composition. For individuals the economic function of a pension scheme is to transfer consumption over time. But (ruling out the case where current output is stored in holes in people's gardens) this is not possible for society as a whole; the consumption of pensioners as a group is produced by the next generation of workers. From an aggregate viewpoint, the economic function of pension schemes is to divide total production between workers and pensioners, i.e. to reduce the consumption of workers so that sufficient output remains for pensioners. Once this point is understood it becomes clear why PAYGO and funded schemes, which are both simply ways of dividing output between workers and pensioners, should not fare very differently in the face of demographic change.

Thus, a review of the literature indicates strongly that prefunded social security systems do not overcome 
the impact of the impending demographic shifts. (This paper discusses the countervailing impact of foreign investment later.) The pension income of any decade must come out of the national income of that decade. However, there may still be reasons to consider a prefunded scheme as economically advantageous.

As Barr (1993, p. 223) later allows, declines in the working-aged population can be offset by increased productivity among the remaining workers or by increased labor force participation rates (for example, among women), so long as output is maintained. It is also, in principle, possible to maintain the consumption of both workers and pensioners with goods produced abroad, provided the country has sufficient overseas assets to do so:

The crucial variable is output. A decline in the labor force causes problems for any pension scheme only if it causes a fall in output; the problem is solved to the extent that this can be prevented. The choice between PAYGO and funding in the face of demographic change is therefore relevant only to the extent that funding (as is sometimes argued) systematically causes output to be higher.

Thus, we have arrived at two important truths. First, no pension plan, private (see Schieber and Shoven 1994) or public, prefunded or paygo, is demographically immune. Second, the real security behind any pension plan is a healthy economy. Wealth cannot be transferred until it is created. And the more wealth that is created, the easier it is to transfer some to the retired elderly.

For prefunding to have any consequence on the security of social security, all three of the following requirements must be satisfied:

- Prefunding must increase gross national savings.

- Those increased savings must be invested in a manner that increases worker productivity.

- The prefunding must be the best way to achieve the first two requirements. If there is an alternative public policy that can increase savings and worker productivity either more efficiently or with less risk, then (by definition) it should be the preferred route (this assumes that no two alternatives have exactly the same impact).

Given these three criteria, how does the literature grade the prefunding of social security as the preferred proposal?

Does the prefunding of social security increase gross national savings (versus, for example, increased hoarding or increased surplus on the current account of the balance of payments)? There is an abundance of literature on this topic (for example, see Ricardo 1817, Daly 1981, Aaron 1982, Barr 1993, Burbidge 1987, or Atkinson 1995), but no clear conclusion. This turns out to be a very difficult question if you allow for behavioral response (or Ricardian equivalence).

For example, one would think that the creation of a paygo social security system, which creates no assets but does provide real retirement income benefits, would necessarily decrease gross national savings. However, the literature finds that this intuitive impact can easily be offset (and was in the U.S. after the introduction of OASDI) by two behavioral responses. First, if the provision of social security results in earlier retirements for workers than would otherwise be possible, those workers will then save as much as before the provision of paygo social security to achieve full economic independence, even with earlier retirement (that is, they still have to save as much privately because they are now providing for a longer period in retirement).

Second, according to the literature, we must factor in the desire of people to create bequests to the next generation before we can know the impact of paygo social security on gross national savings. That is, when younger workers provide their parents with retirement income security through paygo social security, their parents, in turn, work hard to provide an inheritance for their children. Equivalently, there may be the removal of a negative bequest through the advent of social security in that workers no longer need to directly support their parents in retirement. The game may, therefore, be a zero net sum (see Barro 1974 and Poterba 1994).

Of importance here is the replacement rate provided by the social security system. In this regard, Canada and the U.S. are very similar. In both countries, a worker consistently earning the average industrial wage will realize a replacement ratio of about $40 \%$ from the total social security system (in Canada this includes Old Age Security and perhaps some Guaranteed Income Supplement). Poorer workers realize higher replacement ratios, and wealthier workers less. However, the social security system does not, in and of itself, provide full retirement income security-far from it. Thus, other forms of savings are essential. The arguments above about behavioral response may not be as applicable to systems that do provide full retirement income security (for example, some European systems).

In Chile, in 1980 when the social security system was financed on a paygo basis, the gross national 
savings rate was $21.0 \%$. In 1981 , Chile introduced a mandatory individual retirement savings scheme requiring $10 \%$ contributions from all workers and nothing from the employer. The Chilean gross national savings rate dipped substantially in the early 1980 s and stood at $18.8 \%$ in 1991 (Uthoff 1993). In a more recent paper, Holzmann (1997) finds empirical evidence of both increased national savings and enhanced worker productivity in Chile after the 1981 social security reforms. However, Holzmann concludes that "the direct impact of the reform on private saving was low, or perhaps even negative." According to Holzmann, the increase in national savings and the increase in worker productivity were because of higher growth rates in the economy.

Even if gross national savings are increased, has the history of such schemes shown that these savings are invested in a manner that increases worker productivity?

Again, the literature is inconclusive. For every plan that seems to create a healthier economy, there are examples where funds are used for purely political purposes, to reward political friends, to prop up failing industries, or even stolen through straight fraud on the part of the political masters. According to Rosa (1982, p. 212), the experiences of Sweden and Japan (from whom one might expect above-average results in this matter) "offer powerful evidence that this option may only invite squandering capital funds in wasteful, lowyield investments [which] should give pause to anyone proposing similar accumulations elsewhere."

Finally, even if the answers to our first two criteria were positive, is the raising of social security contribution rates to create investable funds the preferred policy option? Aaron (1982), after lengthy empirical analysis of the U.S. savings rates (personal, plus business, plus government, less depreciation) and labor force participation rates from 1930 to the late 1980 s, says no:

If our objective is to increase the rate of capital accumulation, we should ask which instruments are best for achieving that end. Prominent on the list would be direct assaults on the federal deficit, incentives to business investment, and the withdrawal of incentives that promote inefficient investments....

I conclude also that if we wish to increase capital formation, the proper objective is the total saving rate, and that raising social security payroll taxes or cutting social security benefits is a poor device for achieving that objective unless we favor them on other grounds. (Aaron 1982, pp. 51-52)
J. D. Brown (1972) provides another reason for not using social security to create investable funds as the preferred public policy alternative. He argues that social security should not become an instrument of fiscal policy. If the plan is prefunded to any great extent, then contribution rates or benefits might be moved up or down for the impact that would have on the general economy (for example, to dampen inflation). Social security should not be manipulated for such general fiscal motives, according to Brown.

This "fiscal policy" effect was seen in the Singapore National Provident Fund in the early 1980s. When substantial wage awards were made, these were "mopped up" by concomitant increases in the rate of contribution to the Provident Fund (Deutsch and Zowall 1988, pp. $72-81$ ).

\section{Policy Alternatives}

A wide variety of proposals for the privatization of social security have been put forth. This paper examines several of these proposals in their broadest aspect (that is, not with any particular proposal in mind) and attempts to outline their advantages and disadvantages. "Privatization," as discussed below, includes both a shift from paygo social security to more prefunding, with assets invested in the private sector (such as is occurring now in Canada), and the more radical change in which a paygo system is replaced by a defined-contribution individual-account system such as in Chile.

\section{A. Keep Social Security as a Defined- Benefit Plan, but Invest Assets Privately}

Keeping social security as a defined-benefit plan, as is now the case in most systems (including Canada and the U.S.), has a number of advantages, including low administrative costs. Also, by continuing the definedbenefit nature of the program, all participants share in the risks inherent in saving for retirement, including inflation, mortality, selection of investments, and the risk of variable rates of interest at the time when accumulated assets are used to buy a retirement annuity or other retirement income vehicle. Further, it is relatively easy to include important ancillary benefits in a defined-benefit plan, such as disability income and 
survivor income benefits, without having to take regard for the risk profile of any individual participant.

However, the establishment of a higher level of prefunding, and the creation of significant investable funds, as is happening in Canada at this time, have many associated problems. First, if the assets are invested totally in government bonds, has anything been gained over a purely paygo system? Workers are both social security contributors and taxpayers, and it is doubtful that they care about the destination of their paycheck deductions, only the total. In this regard, as the social security system builds up prefunded assets and buys government bonds, governments can use these funds to finance their expenditures while either not raising taxes or actually lowering them. Thus, workers experience higher social security contributions than would be necessary under pure paygo financing but lower general tax rates. The total, however, has not changed as to size or timing.

Similarly, when the baby boomers start to retire, they will demand the return of their government bond IOU. While social security contribution rates will not have to rise when the demographic shift takes place, taxes will have to be raised to pay off the redeemed bonds (unless the government is completely debt free and running an operating surplus). Again, the total burden on workers is exactly the same, in both size and timing, as it would have been on a pure paygo financing basis.

As an aside, the impact on an individual worker may not be quite the same, however. This is because of the difference in effect between a progressive tax regime versus a flat (some would say regressive) payroll tax for social security. Thus, in the lifetime of a worker in the baby-boom generation, the impact of fuller funding would be an increased regressive social security payroll tax but decreased progressive income taxation during the working years, and an increased progressive income tax during retirement.

Thus, except for the important psychological impact that by each generation paying for its social security "in full" they gain a higher moral level of claim on their prospective benefits, the prefunding of social security with all assets being government bonds seems rather pointless. In reality, the financing is still paygo. The total cost of social security to the workers has not changed in any way. In fact, it may work against the creation of a healthier, more productive economy, if these funds are merely used by the government to finance deficits based on consumption-targeted spending (for example, welfare payments). This may be especially important in the U.S. where the OASDI annual surplus is included in the unified federal budget and can be used to mask deficits. The only real debate here is whether payroll taxes (which is what social security contributions are seen to be) have a different impact on labor force productivity than other forms of taxation. This matter is discussed in detail later in the paper.

\section{B. What if the Decision Is to Invest in Private-Sector Assets?}

First, we would have to determine whether the macroeconomic balance sheet has changed at all: that is, if social security stops buying government bonds and buys corporate debt and equities, but the private sector commensurately decreases its purchase of corporate debt and equities and substitutes government bonds, then nothing has changed in total. If the result is not a zero-sum game, then presumably governments have to find new funding means for their debt. One would expect that the government would have to raise its bond interest rates to make this happen. Ultimately, these higher interest charges fall back onto the workers.

Even if that zero-sum game is not the outcome, the ability of a prefunded system to create more savings is highly debatable, as is the ability of such savings, if realized, to create higher productivity. However, the expectation of productivity gains is higher if assets were invested in the private sector, rather than in government bonds, if the economy is undercapitalized. That is an essential part of the public policy processthe determination of the extent to which the economy is undercapitalized.

This "increased savings" could have a perverse effect if it inhibits consumer spending. By saving, we could create the "paradox of thrift," whereby business does not spend on plant and equipment when consumption declines, even with enhanced savings. This is exactly what happened during the Great Depression.

Who will decide how these assets are to be invested? Will they be used for political purposes, for lemon-aid (that is, to prop up ailing industries), or will they end up producing higher levels of wealth creation? Should the investment of these assets be restricted to the domestic market? If so, will that not mean that the social security funds (and government) will have an undue level of control over domestic capital markets and society? 
This was discussed in some detail in the U.S. in 1935 (see Derthick 1979). Under the proposed amendments to the C/QPP, the Canadian government will establish a panel of experts who will work at arm's length from government to invest the funds that will now accrue.

What if the investment is done passively, to achieve an index rate of return? Can the capital markets remain efficient if the majority of investment funds are passively invested? Such funds follow the market rather than leading it. Private capitalism works because management is forced by stockholders to excel. How do passive funds achieve this?

Are there enough high-quality assets available to invest wisely the several hundreds of billions of dollars (trillions in the U.S.) that will become available? This is a particularly interesting point. The funds of a prefunded social security scheme will build up rapidly now as the baby boom prefunds its benefits. However, the same baby boomers will also be saving in their own pension plans and individual accounts for the remainder of their retirement needs. In fact, there are many who claim that today's hot stock market is the result of the influx of these new funds (without any privatization of social security). Thus, it could be argued that the social security system will be buying when asset values are high.

Then, when the baby boom retires, it will force the liquidation of the social security funds to a great extent, again at the same time as the baby boomers are liquidating their other retirement plan assets. As stated by Schieber and Shoven (1994), "This could depress asset prices, particularly since the demographic structure of the United States does not differ that greatly from Japan and Europe, which also will have large elderly populations at that time." Thus, it can be logically argued that a prefunded system is doomed by being in the position of buying high and selling low. In fact, this logical argument concludes that the assumptions upon which the arguments for prefunding social security are based are internally contradictory. The move to prefunding is grounded on the assumption that real rates of return will continue to exceed the growth rate in real wages. If that weren't true, then paygo financing would be preferred. However, how can we continue to expect these current high real rates if we create hundreds of billions of new gross national savings and investable funds?

As an important aside, if the baby boomers attempt to retire over a very short time horizon (they were born over a 15-year period), the drop in asset values intended to fund their retirement if all these assets were offered for sale at the same time, combined with the rise in the price of goods and services as we turn to the baby-bust generation for production of these goods and services, means that realized real retirement income will be lower than expected. That is, there will be free market incentives for later retirement regardless of what is done within the social security programs (Goss 1988, p. 304).

Offshore investment might be preferable for at least three reasons. First, as previously stated, the domestic capital market is not large enough for the prudent investment of such large funds. Second, diversification of risk in any portfolio is generally advised. Third, by investing in countries that do not share the aging populations of Canada or the U.S. (that excludes all of Europe, Japan, Australia, and New Zealand), or countries where workers do not care to retire at some fixed or early age (presumably developing nations), it might be possible to dampen the impact of the impending retirement of the baby-boom generation in North America. This might be referred to as demographic profile diversification. Interestingly, this might also decrease or eliminate the need for government-sponsored foreign aid.

However, this is not without some significant investment risk and political difficulties. One could expect heated debate if it were suggested that social security should build up large investable funds, only to have them invested offshore.

There are other problems associated with a prefunded social security, however, even if invested widely in the private sector. First, prefunded schemes are exposed to the risk of unforeseen inflation (that is, inflation that decreases real rates of return) because of the length of time between contribution and payment of retirement income. In this regard, inflation nearly destroyed several funded schemes in Europe earlier in this century (for example, France and Germany; see Linton 1935, p. 365). This may be one reason that these schemes now are funded on close-to-paygo financing. Prefunded provident funds that exist in many developing countries are also experiencing problems with the effects of inflation.

Second, with the creation of these large investment funds, there will be strong and continuous pressure to expand social security benefits in an era when such expansion would be misguided public policy. The history of the C/QPP provides strong evidence for this. Because of low early contribution rates and a healthy contingency fund, politicians steadily increased the benefits of the C/QPP during its first 25 years. Based on 
the latest actuarial projections, of the $14.2 \%$ ultimate contribution rate required to fund the C/QPP, 2.4 percentage points come from the expansion of benefits just mentioned (CIA 1996, p. 46). This reason also was often used to continue basic paygo financing for OASDI over its early years (see Derthick 1979, Chapter 11).

Finally, the creation of funds to invest requires that social security contribution rates must be set higher initially, in the short run, than those required under pure paygo financing. Is this optimal public policy? Several reasons indicate why the answer might be no.

First, evidence suggests that social security contributions, whose impact is the same as payroll taxes, could hurt job creation:

These [social security contribution rate] increases have had and will continue to have a negative impact on the labor force. [Between 1986 and] 1993, the rise in contributions by employers and employees had reduced employment and the participation rate by nearly 26,000 jobs and 0.12 percentage points, respectively. By the year 2016, the increase in C/QPP contributions will have reduced the participation rate by approximately 0.5 percentage points. (Italianno 1995)

This effect is especially pronounced if social security taxes are levied on only part of the worker's income (for example, in Canada, C/QPP contributions are levied only up to the year's maximum pensionable earnings, which is roughly the average industrial wage, while in the U.S., contributions to OASDI cease at $\$ 65,400$ in 1997). Raising social security contribution rates would have the effect of providing an incentive to pay for overtime instead of hiring new staff. Would it not be preferable to assist job creation now, even if it means higher potential contributions when the baby boom retires, but also when there could easily be labor shortages?

Second, social security contributions are a part of total government taxation. There must be a maximum rate of taxation beyond which actual cash tax receipts decline. Prior to this, resistance to increased taxation will be evident in the proportion of the economy that evades taxation (that is, the underground or cash economy). So long as government debt exists, is it optimal government policy to increase social security contributions to create huge social security funds or to increase some other form of tax and decrease the deficit and the debt? The level of noncompliance in the Chilean system can be partly explained by this taxationlimit phenomenon.

Third, we may find better ways to increase national savings rates and productivity than to prefund social security. Any government action that increases saving for retirement could be substituted for prefunded social security if the goal is to increase savings and productivity. Clearly, the increased (mandatory) contribution rates needed to prefund social security will decrease the total dollars that can be saved for retirement in any other vehicle and lessen the amount invested in private alternatives. It is surprising, therefore, not to hear more opposition to the prefunding of social security from private-sector-retirement professionals.

Mandating employer-sponsored private pensions or even creating stronger incentives (or weaker disincentives) to private pensions and individual savings accounts (RRSPs in Canada) could have the same effect on savings and productivity. In fact, it might be preferable because it does not bring with it the possibility of undue government influence and does not create any pressure for increasing social security benefits (Derthick 1979, Chapter 11). Is it not better to concentrate on the economic goals directly, rather than on the attempt to achieve them as a by-product of social security financing?

It seems very strange that in both Canada and the U.S. the government is seriously considering a prefunded social security scheme, while at the same time it is putting more limits on the ability of employers and workers to save through private pension schemes and individual accounts (see federal budgets in both countries over the past five years). As long as there is an alternative to prefunded social security that can have the same probability of enhancing savings and productivity, then, for the reasons just listed, it should be the preferred public policy.

Earlier it was noted that the prefunding of social security might create a higher moral claim for the generation that paid for the full cost of benefits. This argument is stronger if the assets so created are invested in the private sector, as opposed to buying government bonds. Through the social security system, workers would become owners of capital and could expect to receive a fair rate of return on this capital after they retire. Although this is a strong argument, it still depends entirely on this capital being new and additional and on the capital being used to enhance worker productivity. Again, the basic truths have not changed.

\section{Change Social Security to a Defined-Contribution Plan}

Another possibility is to turn the present defined-benefit social security system into a defined-contribution 
scheme in which participants decide how their individual funds are invested. This is an analogy to the Chilean social security reforms, which are discussed in Section IV.D. Several countries have reformed their pension systems along the same lines as Chile did in 1981, including Peru in 1993, Argentina in 1994, Colombia in 1994, and Mexico in 1997. Bolivia and Ecuador are considering it.

Certainly it is possible to retain many of the obvious advantages of today's social security system within a defined-contribution scheme. All workers can be covered. Vesting can be immediate. Portability is a given. However, such a shift also has several disadvantages.

First, all the risks of a defined-contribution plan, including the investment risk, the inflation risk, and the mortality risk, would fall on the shoulders of the individual worker instead of being shared across the entire population and across generations. As a result, any resulting assets would be invested in less risky instruments than if the plan were left as a defined-benefit plan but in the private sector. This, in turn, would be expected to result in lower long-term rates of return. This is extremely important since, for example, $1 \%$ of extra return over the lifetime of a worker would result in a pension that is about 24\% larger (see Adams 1967). Even if the only concern is the cost of purchasing an annuity at the time of retirement, $2 \%$ of extra return translates into a retirement annuity that is about $17 \%$ larger for a fixed purchase price (Coward 1991, p. 66).

Second, the ancillary benefits of the present social security system, including disability and survivor benefits, would be lost or would have to be replaced by a parallel system of some kind. In Chile, extra contributions are required for these benefits, which are purchased from private insurers.

Third, administrative expenses for such a scheme would be much higher than under today's system. In Chile, with advertising costs and sales commissions, expenses have run from $12 \%$ to $15 \%$ of cash flow versus the $1.3 \%$ expense ratio for the $\mathrm{C} / \mathrm{QPP}$, and $0.8 \%$ for OASDI.

Fourth, there may not be enough high-quality assets to match the investable funds now available. In times of poor investment returns, the government may be blamed and may be asked to provide minimum guarantees (which lead to economic distortions and possible antiselection).

Fifth, there is no wealth distribution in such a scheme. A worker who is poor throughout his or her working lifetime is guaranteed poverty in retirement. Similarly, the wealthy worker is guaranteed a wealthy retirement, aided by the tax advantages provided the scheme. In Chile, the results have actually been regressive. Because many of the sales and administrative expenses are per account and not per dollar of cash flow, smaller accounts have paid higher expense ratios than have larger accounts.

Sixth, without special legislation, females retire with lower retirement income than do males of identical work and contribution records, because of the higher female life expectancy. In Canada, females would also lose the child-rearing dropout provisions of the C/QPP. In the U.S., the dependent spouse benefit would disappear.

Seventh, the transition generation may have to pay twice: first, to fund the new defined-contribution scheme and, second, to pay for the accrued actuarial liability of the previous system (that is, the benefits promised by the previous system or about $\$ 600$ billion in Canada and about ten times that in the U.S.). Note that it would be 30 to 40 years before the new definedcontribution scheme could pay out anything close to full benefits. In the meantime, the government is responsible for the previous accrued liability runoff. These accrued liabilities are now explicitly part of the national debt. If this debt is financed with something like the recognition bonds being used in Chile, then the first generation under the new scheme would have to pay for both its own new scheme and the debt of the recognition bonds for the previous accrued liability.

The economic impact of this is not immediately clear. Under a paygo social security system, there is an implicit government debt equal to the unfunded accrued actuarial liability of the system. By shifting to a defined-contribution system and issuing recognition bonds equal in value to the accrued benefits of qualified workers, the government has simply made this debt explicit. The recognition bonds do not have to be paid off by the first generation of workers any more than any one generation of workers is expected to pay off the national debt. However, to the extent that it is actually financed in this manner, the transition generation faces double taxation and is poorer to that extent. (The next generation is equivalently wealthier by not having this debt.)

Eighth, if the Chilean experience is any indication, there will probably be a need for some government guarantee of a minimum benefit under the new system (which, unless designed skillfully, can be open to abuse and antiselection).

Finally, is there political justification for a free government forcing individual savings when there is no 
wealth distribution component? As long as there is some income redistribution, the general welfare argument can be used to defend such systems, but what happens when there is no wealth distribution?

\section{The Chilean Model Reviewed}

The new Chilean social security system was decreed in 1981. Rather than a government-run paygo scheme(s) (as had previously existed in Chile), the new system requires that employees contribute $10 \%$ of pay to one of 15 investment fund agencies (called AFPs). There is also a $3.5 \%$ (approximately) contribution to cover disability income benefits and survivor benefits (provided by private insurance companies). Employers do not contribute, nor do members of the military or the self-employed. At the time that these $13.5 \%$ contributions were mandated, workers were granted an $18 \%$ pay increase (employers incurred this increase but saw their large social security contributions disappear).

Of all eligible workers, $86 \%$ are affiliated with the new system, but only $55 \%$ of the labor force are contributing members. This represents a high level of noncompliance, apparently mostly from poor workers who will receive the minimum benefit regardless. The government is responsible for all accrued liabilities of the old paygo system and has issued recognition bonds equal in value to the accrued social security benefits for all previous participants who qualify (workers who only had a very short work history under the old social security system were not given any recognition of their accrued benefits). The government also limits the extent to which the rate of return provided by one pension fund can fall below that of the average AFP rate of return and, after annuitization, guarantees annuity payments if the insurance company fails $(100 \%$ of the minimum pension is guaranteed, plus $75 \%$ of the rest of the benefit up to a specified limit). Finally, the government guarantees a minimum benefit under the new system for those who have at least 20 years of coverage under both the old and new plans. If the individual account plus the value of the recognition bond do not create a pension of $85 \%$ of the legal minimum wage ( $90 \%$ for those aged 70 or over), or about $30 \%$ of the average wage in the country, the government pays the difference. The costs of these guarantees are financed through general tax revenues, which is equivalent to paygo financing.

If the new AFP system can earn an average $7 \%$ real rate of return over the lifetime of the average worker, then the new system should provide benefits as large as the old paygo system (assuming only a small change in life expectancy). While the plan did earn such rates in its early years, these would be considered to be very high for a mature economy.

Under the new plan about $40 \%$ of total assets are invested in government bonds, which means that to this extent the new plan is still paygo.

As noted earlier, in 1980, under the old paygo financing system, gross national savings in Chile were $21.0 \%$ of GDP. After the introduction of the new mandatory individual savings scheme, savings rates dipped in the 1980s and stood at $18.8 \%$ of GDP in 1991 (Uthoff 1993).

Obviously the system includes only wage and salaried employees (for example, not homemakers), and retirement benefits are a direct function of lifetime earnings; that is, there is no redistribution of wealth in the system except for the guaranteed minimum benefit.

All risks (for example, the investment risk, inflation, mortality) are transferred to the individual worker, except for the minimum guarantees listed above.

This generation of workers will, in effect, be paying twice, once to fund their own retirement through the new system (through contributions) and once to pay off the recognition bonds for the accrued liabilities of the old paygo system (through general taxation).

AFP expense ratios for sales commissions, advertising, and general administration are high. Myers (1992) reported that they are $15 \%$ of the contributions (higher for lower-wage earners and lower for higher contributors, because part of the fee is flat rate, which makes them regressive). Some estimates now put total sales costs as high as $26 \%$ of contributions (Orgill 1996), as salespeople, trying to maximize their commissions, encourage members to switch funds often. This is such a concern that Chile is considering placing restrictions on the ability to switch (such restrictions already exist in Argentina). These Chilean expense ratios compare to ratios of $1.3 \%$ for the C/QPP and $0.8 \%$ for OASDI.

Almost all $(99.8 \%)$ of the assets are invested in the Chilean economy. This appeared to be sound policy in the early years of the system because rates of return averaged 13\%. However, in 1995, the AFPs experienced net losses because the Santiago Bourse performed badly (Orgill 1996). There is now general discussion about diversifying the investment funds outside of Chile.

So while the Chilean system of mandatory individual savings accounts has been "studied and touted as a model from Britain to Uzbekistan, Chile's free-market 
pension system is suddenly facing a host of challenges: falling returns, soaring costs, and an overdependence on local economic savings" (Myers 1992).

This paper has explored at some length the advantages and disadvantages of the prefunding of social security. The thesis is that any public policy that purports to enhance the security of social security must satisfy (all) three criteria:

- It must increase gross national savings.

- Those savings must be used in a manner that increases worker productivity.

- A better method of achieving the first two stated goals cannot exist.

This paper has reviewed a variety of currently proposed alternatives to the financing of social security under these three criteria and has found many unanswered questions and unsatisfied concerns.

In short, any move away from the present close-topaygo financing of social security in Canada and the U.S. cannot be defended as preferred public policy.

\section{REFERENCES}

Aaron, Henry J. 1982. Economic Effects of Social Security. Studies of Government Finance. Washington, D.C.: The Brookings Institute.

Aaron, Henry J., ed. 1988. "Social Security and the Budget," Proceedings of the First Conference of the National Association of Social Insurance. Washington, D.C.: University Press of America.

Aaron, Henry J., Bosworth, Barry P., and Burtless, Gary. 1992. Can America Afford to Grow Old? Paying for Social Security. Washington, D.C.: The Brookings Institute.

Adams, Warren R. 1967. "The Effect of Interest on Pension Contributions," Transactions of the Society of Actuaries XIX:170-93.

Asimakopulos, A. 1984. "Financing Canada's Public Pensions-Who Pays?" Canadian Public Policy $X$, no. 2:156-66.

Atkinson, A. B. 1995. "Is the Welfare State Necessarily an Obstacle to Economic Growth?" European Economic Review 39:723-30.

Barr, Nicholas. 1993. The Economics of the Welfare State. London: Weidenfeld and Nicolson.

Barr, Nicholas, and Whyres, David, eds. 1993. Current Issues in the Economics of Welfare. New York: St. Martin's Press.
Barro, R. J. 1974. "Are Government Bonds Net Wealth?" Journal of Political Economy 82:10951118.

Bayo, F. 1988. "Measures of Actuarial Balance for Social Insurance Programs," Record of the Society of Actuaries 14, no. 1:161-80.

Beattie, Roger, and McGillivray, Warren. 1995. "A Risky Strategy: Reflections on the World Bank Report Averting the Old Age Crisis," International Social Security Review, issue 3-4/95. Geneva: International Labor Office and International Social Security Association.

Brown, J. Douglas. 1972. An American Philosophy of Social Security. Princeton, N.J.: Princeton University Press.

Brown, Robert L. 1997. Introduction to the Mathematics of Demography. 3rd ed. Winsted, Conn.: Actex Publications.

Burbidge, John. 1987. Social Security in Canada: An Economic Appraisal. Canadian Tax Foundation Paper no. 79. Toronto: Canadian Tax Foundation.

Canadian Institute of Actuaries. 1995. Troubled Tomorrows-The Report of the Canadian Institute of ACtuaries Task Force on Retirement Savings. Ottawa: Canadian Institute of Actuaries.

Canadian Institute of Actuaries. 1996. Report of the Task Force on the Future of Canada/Quebec Pension Plans. Ottawa: Canadian Institute of Actuaries.

Coward, Laurence E. 1991. Mercer Handbook of Canadian Pension and Benefit Plans. 10th ed. Don Mills: CCH Canadian Limited.

Daly, Michael. 1981. The Effect of the Canada Pension Plan on Personal Retirement Saving: Some New Evidence from Cross-Section Tax Data. Ottawa: Economic Council of Canada.

Daly, Michael, and Wrage, Peter. 1981. The Impact of Canada's Old Age Security Program on Retirement Saving, Labour Supply and Retirement. Ottawa: Economic Council of Canada.

Dawson, Miles M. 1917. "Public Pension System on a Reserve Basis?" Record of the American Institute of Actuaries VI:90.

Department of Finance. 1996. An Information Paper for Consultations on the Canada Pension Plan. Ottawa: Government of Canada, Department of Finance.

Derthick, Martha. 1979. Policy Making for Social Security. Washington, D.C.: The Brookings Institute.

Deutsch, Antal, and Zowall, Hanna. 1988. "Compulsory Savings and Taxes in Singapore." Research Notes 
and Discussions Paper No. 65. Singapore: Institute of Southeast Asian Studies, Economic Research Unit.

Di Matteo, L., and Shannon, M. 1995. "Payroll Taxation in Canada: An Overview," Canadian Business Economics (summer):5-22.

Edwardh, Tony. 1995. The AFP: Chile's Response to Income Security in Old Age: Towards Dystopia. McMaster University Summer Institute on Gerontology: Aging Workforce, Income Security and Retirement, June 7-9, Hamilton.

Goss, S. 1988. "Long-Range Costs of Social Insurance," Record of the Society of Actuaries 14, no. 1:271-304.

Greene, Geoffrey. 1989. "Demographics and the Decline in the Saving Rate," DRI/McGraw-Hill U.S. Long-Term Review (fall):31-38.

Hohaus, Reinhard A. 1936. "Reserves for National Old Age Pensions: Are They Necessary or Desirable under a Compulsory Contributory Plan?-A Review of Actuarial Opinion," Transactions of the Actuarial Society of America XXXVII:330-65.

Holzmann, Robert. 1997. Pension Reform and National Saving: The Chilean Experience. South Africa: University of Saarland, Department of Economics.

Italianno, Joe. 1995. Growth in Supplementary Labour Income: Implications for Tax Revenue, Employment and Participation. Ottawa: Department of Finance.

James, Steven, Matier, Chris, Sakhnini, Hurnam, and Sheikh, Munir. 1995. The Economics of Canada Pension Plan Reforms. Working Paper 95-09. Ottawa: Department of Finance.

Kotlikoff, Laurence J. 1988. "Intergenerational Transfers and Savings," Journal of Economic Perspectives 2 , no. 2 (spring):41-58.

Kotlikoff, Laurence J., Smetters, Kent, and Walliser, Jan. 1996. "Privatizing U.S. Social Security -A Simulation Study." World Bank Economic Development Institute November Conference: Pension Systems: From Crisis to Reform.

Krugman, Paul. 1996. "A Country Is Not a Company," Harvard Business Review' (January/February):40-51.

Kune, Jan B. 1995. "Macro and Micro Considerations in Respect of Financing Complementary Pension Schemes." Report for the 11 th International Conference of Social Security Actuaries, Athens.

Linton, M. Albert. 1935. "Reserve Provisions of the Federal Old Age Security Program," Transactions of the Actuarial Society of America XXXVI:363-80.
Mitchell, O. S., and Zeldes, S. P. 1996. "Social Security Privatization: A Structure for Analysis," American Economic Review 86, no. 2:363-67.

Modigliani, Franco. 1988. "The Role of Intergenerational Transfers and Life Cycles Saving in the Accumulation of Wealth," Journal of Economic Perspectives 2, no. 2 (spring): 15-40.

Moorhead, Ernest J., and Trowbridge, Charles L. 1977. "The Unresolved Decoupling Issue," Transactions of the Society of Actuaries XXIX:429-52.

Myers, Robert J. 1992. "Chile's Social Security Reform (after Ten Years)," Benefits Quarterly 8, no. 3:4155; addendum, 9, no. 1:102.

Nagnur, Dhruva. 1991. Longevity and Historical Life Tables 1921-1981 (Abridged), Canada and the Provinces. Ottawa: Statistics Canada Ministry of Supply and Services.

Orgill, Margaret. 1996. "Chile's Pension System Faces Challenges," Reuter's News Service, Santiago (electronic), June 20.

Poterba, J. M., ed. 1994. Public Policies and Household Saving. Chicago: University of Chicago Press for the National Bureau of Economic Research.

Ricardo, David. 1817. On the Principles of Political Economy and Taxation. Reprinted in 1971, edited by R. M. Hartwell. London: Penguin Books.

Richter, O. C., and Williamson, W. R. 1935. "The Social Security Act of 1935 and the Work of the Committee on Economic Security," Transactions of the Actuarial Society of America XXXVI:299-362.

Robson, William B. P. 1995. Putting Some Gold in the Golden Years: Fixing the Canada Pension Plan. C. D. Howe Commentaries no. 76. Toronto: C. D. Howe Commentary.

Rosa, Jean-Jacques. 1982. The World Crisis in Social Security. San Francisco, California, Foundation Nationale d'Économie Politique and Institute for Contemporary Studies. New Brunswick, N.J.: Transaction Books.

Schieber, S. J., and Shoven, J. B. 1994. "The Consequences of Population Aging on Private Pension Fund Saving and Asset Markets." National Bureau of Economic Research Working Paper No. 4665. Cambridge, Mass.: National Bureau of Economic Research.

Singh, Ajit. 1996. "Pension Reform, the Stock Market, Capital Formation and Economic Growth: A Critical Commentary on the World Bank's Proposals," International Social Security Review 49, no. 3:1-23. 
Slater, David. 1995. "Reforming Canada's Retirement Income Security System," Canadian Business Economics no. 1:47-58.

Smith, Lee. 1988. "Trim That Social Security Surplus," Fortune 118, no. 5 (August 29):84-89.

Treuil, Pierre. 1981. "Fund Development of an Earnings-Related Social Insurance Plan under Stabilized Conditions," Transactions of the Society of Actuaries XXXIII:231-50.

Uthoff, A. W. 1993. "Pension System Reform in Latin America," in Finance and the Real Economy, edited by Y. Akyuz and G. Held. Santiago, Chile: ECLAC, UNCTAD, UNU.
Weil, David N. 1993. “Intergenerational Transfers, Aging, and Uncertainty." Working Paper No, 4477. Cambridge, Mass.: National Bureau of Economic Research.

Wilkin, J. C., Bailin, S., Goss, S. G., and Rowley, T. A. 1988. "Long Range Costs of Social Insurance," Record of the Society of Actuaries 14, no. 1:271-304.

Wilkin, J. C., Bartlett, D. K., III, Bayo, F., Gottlieb, B. I., and Myers, R. J. 1988. "Measures of Actuarial Balance for Social Insurance Programs," Record of the Society of Actuaries 14, no. 1:161-79.

World Bank. 1994. "Averting the Old Age Crisis: Policies to Protect the Old and Promote Growth." World Bank Policy Research Report. New York: Oxford University Press. 